\title{
Upaya Meningkatkan Partisipasi dan Minat Masyarakat terhadap Koperasi Syariah Bmt At-Tin
}

\author{
Ahamd Calam*1, Dewi Purnama Sari², Dian Aryanto ${ }^{3}$ \\ ${ }^{1}$ Dosen STMIK Triguna Dharma dan Ketua STKIP Amal Bakti \\ ${ }^{2}$ Dosen STKIP Amal Bakti \\ 3 Mahasiswa STKIP Amal Bakti \\ *e-mail: calamahmad223@gmail.com ${ }^{1}$
}

\begin{abstract}
Abstrak
Koperasi syariah atau yang disebut Koperasi Simpan Pinjam Pembiayaan Syariah (KSPPS) merupakan identitas keuangan mikro syariah yang unik dan spesifik khas Indonesia. KSPPS dalam melaksanakan fungsi dan perannya menjalankan peran ganda yaitu sebagai lembaga bisnis dan disisi yang lain melakukan fungsi sosial yakni menghimpun, mengelola dan menyalurkan dana ZISWAF. Metode yang digunakan dalam pengabdian ini adalah pengabdian kualitatif dengan analisis deskriptif. Tujuan dari pengabdian ini adalah; Meningkatkan kesejahteraan hidup anggota pada khususnya dan masyarakat pada umumnya, Menjadi gerakkan ekonomi serta ikut tatanan perekonomian nasional, Ikut membangun tatanan perekonomian nasional dalam rangka mewujudkan masyarakat yang maju, adil dan makmur berdasarkan pancasila dan undang -undang dasar 1945, Menggiatkan kesadaran anggota untuk mengumpan pada koperasi secara teratur dan Meningkatkan pengetahuan anggota melalui penyuluhan latihan dan pendidikan tentang perekonomian maupun keterampilan lainnya sesuai syariah. Adapun manfaat dari pengabdian ini adalah; Masyarakat dapat memulai suatu usaha dengan keikutsertaan dalam keanggotaan koperasi dan dapat mengetahui syarat-syarat apa saja yang diperlukan untuk menjadi nasabah yang mempunyai simpanan berjangka (deposito) di koperasi BMT AT-TIIN. Hasil pengabdian ini membangun efektifitas pengawasan Dewan Pengawan Syariah (DPS) terhadap koperasi syariah yaitu peran dan fungsi DPS di KSPPS BMT AT-TIIN telah sesuai dengan aturan yang ditetapkan oleh Bank Indonesia dimana DPS memiliki tiga kedudukan, diantaranya sebagai penasihat dan pemberi saran, sebagai mediator antar lembaga keuangan syariah dengan DSN-MUI dalam mengkomunikasikan usul dan saran pengembangan produk, dan sebagai perwakilan DSN yang ditempatkan pada lembaga keuangan syariah.
\end{abstract}

Kata kunci: BMT AT-TIIN. Koperasi Syariah, Peningkatan

\begin{abstract}
Sharia cooperatives or the so-called Sharia Financing Savings and Loans Cooperatives (KSPPS) are a unique and specific Islamic microfinance identity that is unique to Indonesia. KSPPS in carrying out its functions and roles carries out a dual role, namely as a business institution and on the other hand carries out social functions, namely collecting, managing and distributing ZISWAF funds. The method used in this service is qualitative service with descriptive analysis. The purpose of this service is; Improving the welfare of members' lives in particular and society in general, Being an economic movement and participating in the national economic order, Participating in building the national economic order in order to create an advanced, just and prosperous society based on Pancasila and the 1945 Constitution cooperatives regularly and Increase the knowledge of members through training and education counseling about the economy and other skills according to sharia. The benefits of this service are; The community can start a business by participating in cooperative membership and can find out what conditions are needed to become customers who have time deposits (deposits) in the BMT AT-TIIN cooperative. The results of this service build the effectiveness of the supervision of the Sharia Supervisory Board (DPS) on sharia cooperatives, namely the role and function of the DPS in KSPPS BMT AT-TIIN in accordance with the rules set by Bank Indonesia where DPS has three positions, including as an advisor and adviser, as a mediator. between Islamic financial institutions and DSNMUI in communicating product development proposals and suggestions, and as representatives of DSN placed in Islamic financial institutions.
\end{abstract}

Keywords: BMT AT-TIIN, Improvement, Sharia Cooperatives

\section{PENDAHULUAN}

Koperasi syariah merupakan koperasi yang menjalankan usaha dibidang simpan pinjam dan pembiayaan yang menggunakan prinsip-prinsip syariah. Dimasa lalu, koperasi syariah 
dikenal dengan sebutan Baitul Maal Wat Tamwil (BMT). Baitul Maal wat Tamwil (BMT) adalah lembaga keuangan mikro yang dioperasikan dengan prinsip bagi hasil untuk menumbuhkembangkan derajat dan martabat serta membela kepentingan kaum fakir miskin, ditumbuhkan atas prakarsa dan modal awal dari tokoh-tokoh masyarakat setempat dengan berlandaskan pada sistem ekonomi yang salaam. Secara yuridis keberadaan BMT didasarkan pada Undang-Undang Republik Indonesia No. 25 Tahun 1992 tentang perkoperasian pasal 44 ayat 3 yang berbunyi "Pelaksanaan kegiatan usaha simpan pinjam oleh koperasi diatur lebih lanjut dengan peraturan pemerintah". Sedangkan peraturan pemerintah yang berkaitan dengan tersebut adalah peraturan pemerintah No. 9 tahun 1995 tentang pelaksanaan kegiatan usaha simpan pinjam oleh koperasi yakni berbunyi "Pemberian imbalan dapat berupa bunga atau dalam bentuk lainnya berupa prinsip bagi hasil". Namun terbitnya Keputusan Meteri Negara Koperasi dan Usaha Kecil dan Menengah RI Nomor 91/Kep/M.KUKM/91X/2004 tentang petunjuk pelaksanaan. Namun sejak tanggal 25 September 2015, pemerintah menerbitkan Peraturan Menteri Koperasi dan Usaha Kecil Menengah Republik Indonesia Nomor 16/Per/M.KUKM/IX/2015 Tentang Pelaksanaan Kegiatan Usaha Simpan Pinjam dan Pembiayaan Syariah oleh koperasi. Peraturan Menteri ini merubah status KJKS menjadi KSPPS.

Data dari Badan Pusat Statistik (BPS) menunjukkan bahwa jumlah koperasi di seluruh Indonesia pada tahun 2015 sebanyak 150.223 unit. Harapannya, dengan angka tersebut koperasi mampu membantu masyarakat kecil dalam memperoleh pinjaman sehingga dapat meringankan dalam pemenuhan kebutuhan hidupnya. Namun, berdasarkan data dari Badan Pusat Statistik (BPS) pada Maret 2016 jumlah penduduk Indonesia yang berada dalam kategori miskin mencapai 28,01 juta orang atau sebesar 10,86\%. Oleh karena itu, dibentuklah Koperasi Simpan Pinjam Syariah atau Koperasi Jasa Keuangan Syariah (KJKS) serta Unit Jasa Keuangan Syariah (UJKS) dengan harapan dapat meningkatkan kesejahteraan masyarakat Indonesia, khususnya pada kalangan masyarakat menengah kebawah dan mewujudkan keadilan sesuai dengan konsep Islam.

Tidak seperti lembaga keuangan (bank) konvensional, yang pada dasarnya berperan sebagai peminjam dana disatu pihak dan pinjaman dana dilain pihak, lembaga keuangan syariah (KSPPS) pada dasarnya adalah mitra bagi para anggotanya. Koperasi Syariah menghimpun dana dari anggota melalui kontrak mudharabah yang dapat dibatasi oleh waktu, atau tujuan, atau keduanya, dan dengan demikian menjadi mitra kelola selama berlakunya perjanjian. Begitu Koperasi Syariah menjalin kontrak mudharabah dengan anggota, ia akan menggunakan danadana itu melalui berbagai macam perjanjian yang dibolehkan syariah : mudharabah, musyarakah, murabahah, ijarah, dan seterusnya. Mekanisme bagi hasil merupakan keuntungan yang ditawarkan oleh koperasi syariah kepada anggota yang menyimpan uangnya dalam kontrak/akad mudharabah, maka koperasi syariah perlu mengimplementasikan sistem bagi hasil yang menawarkan kepada anggotanya.

Saat ini, permasalahan utama koperasi syariah adalah loyalitas anggotanya. Pengaruh isu-isu yang muncul di media informasi masih dianggap berita yang bisa diakui kebenarannya. Tentunya hal ini menjadi tantangan semua pihak yang berkepentingan dengan usaha koperasi baik departemen terkait ataupun para pelaku usaha koperasi untuk melakukan pembuktian.

\section{METODE PELAKSANAAN}

\section{a. Analisa Masalah}

Adapun uraian tahapan pelaksanaan program yaitu sebagai berikut:

\section{Tahap Perencanaan}

Tahap perancanaan dilakukan dengan pembentukan tim PKM-M yang terdiri dari 5 orang dan selanjutnya menyusun proposal yang kemudian diajukan. Program ini akan dilaksanakan dari bulan September 2020 sampai dengan Februari 2021.

\section{Tahap Persiapan}

Tahap persiapan dilakukan selama satu minggu yaitu berupa melakukan kesepakatan kerjasama dengan Ketua dari Koperasi Syairah BMT AT-TIIN, penyusunan jadwal kegiatan, 
penentuan tempat sosialisasi yaitu di sekolah Mis Al-Hidayah , serta pembelian peralatan dan bahan.

\section{Tahap Pelaksanaan Sosialisasi}

Tahap ini sebagai bentuk kegiatan sosisalisasi dalam pengembangan koperasi, tahap ini bertujuan sebagai gambaran awal rencana program database Koperasi Syariah BMT AT-TIIN.

\section{Tahap Evaluasi}

Tahap evaluasi dilakukan untuk memberikan solusi dari permasalahan yang dihadapi oleh masyarakat dan pengurus koperasi. Indikator keberhasilan pada tahap ini adalah didapatkan solusi dari permasalahan tersebut, menjadi acuan untuk kedepannya serta terus berkembang dan berjalannya program ini, selain itu indikator keberhasilan lainnya adalah naik pendapatan

\section{b. Kerangka Masalah}

\section{Hasil}

Hasil dari pelaksanaan project program kreativitas mahasiswa ini adalah dapat membantu meringankan beban tugas dari pihak Koperasi Syariah BMT AT-TIIN dan juga membuat usaha koperasi tersebut menjadi lebih berteknologi dan berkembang maju. Adapun hasil rancangan desain yang kamu buat sebagai berikut :

\section{Desain Antar Muka}

Berikut dijelaskan sebagian dari desain antar muka sistem koperasi simpan pinjam diantaranya:

i. Form Login

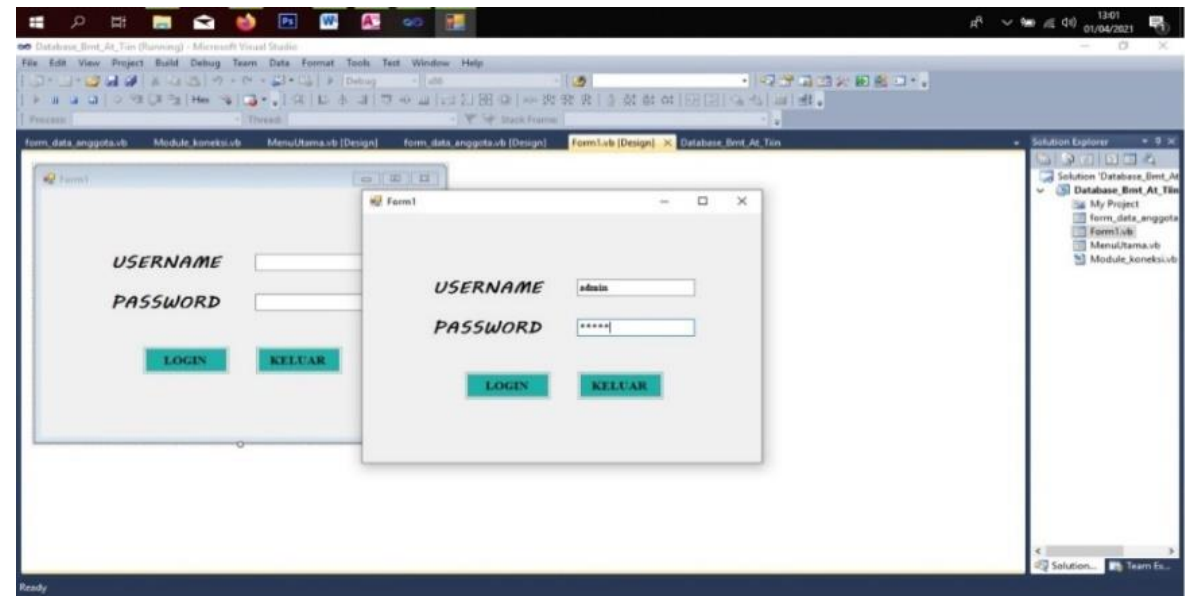

Gambar 1. Form Login

ii. Form Menu Utama

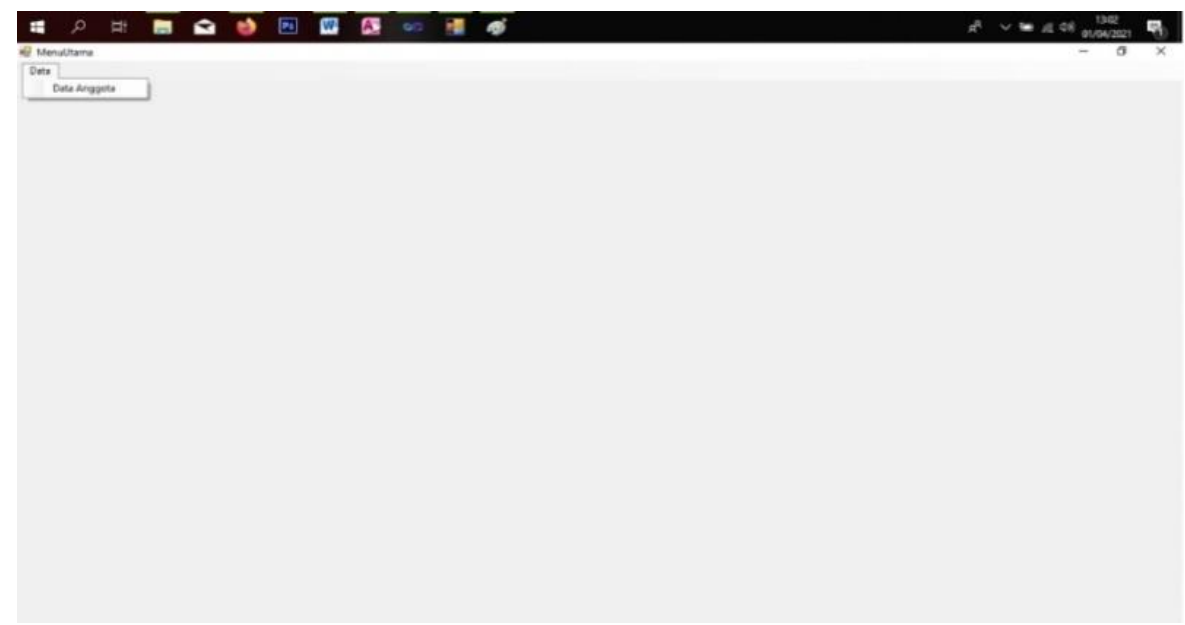

Gambar 2. Form Menu Utama 
iii. Form Data Anggota

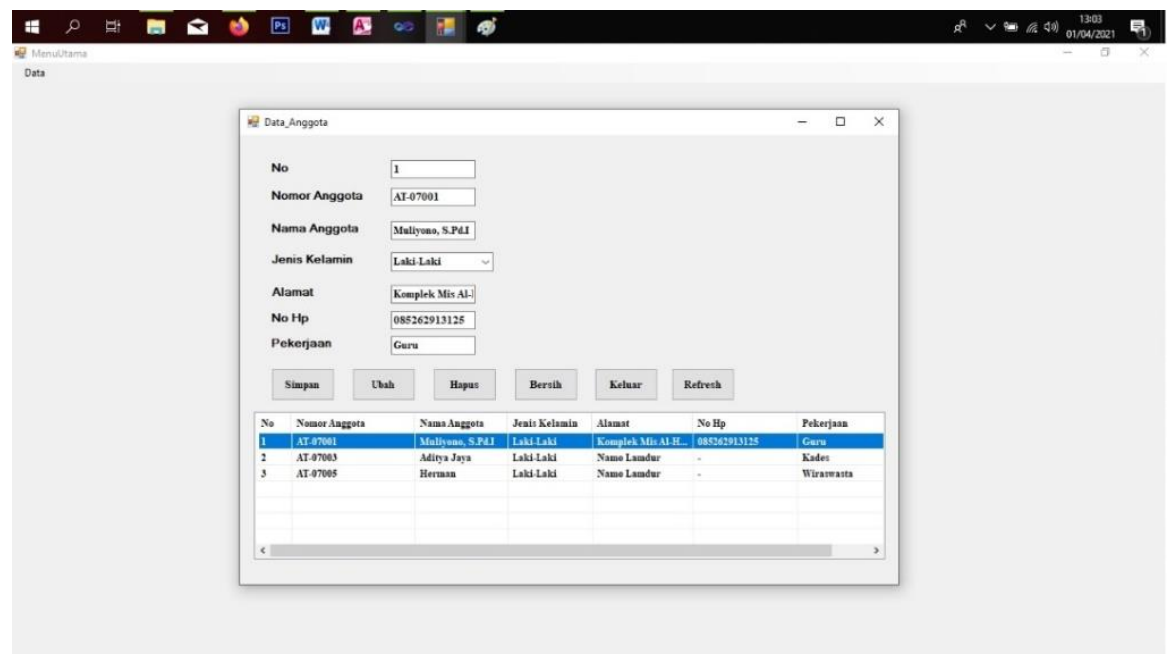

Gambar 3. Form Data Anggota

\section{HASIL DAN PEMBAHASAN}

\section{a. Lokasi Kegiatan Pengabdian}

Pengabdian ini di lakukan di Jl. Perintis Kemerdekaan , Desa Namo Rambe ,Kec. Namo Rambe ,Kab. Deli Serdang.

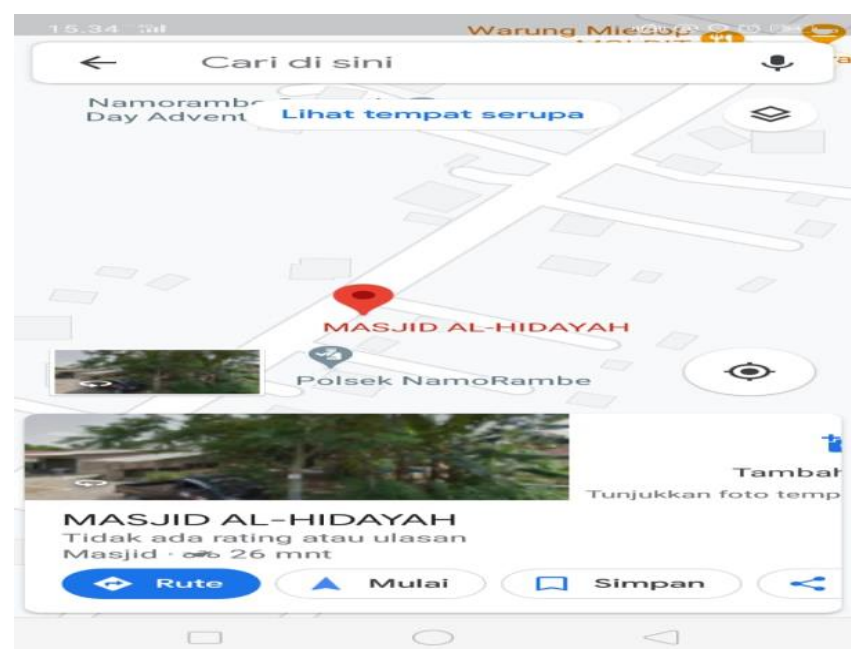

Gambar 4. Maps Lokasi Pengabdian

\section{b. Kondisi Masyarakat}

Koperasi ini diprakarsai oleh ketua yang bernama Bapak Muliyono, S.pd.I dengan merekrut beberapa rekan-rekannya untuk mendirikan sebuah lembaga keuangan mikro syariah. Dalam rangka untuk membantu masyarakat agar terhindar dari riba. Dalam pertumbuhan dan perkembangan koperasi secara umum masih tergolong lmbat dan kecil. Namun termasuk koperasi yang tangguh dan kuat bertahan. Dimana banyak koperasi sejenis yang berdiri pada kurun waktu tersebut di Deli Serdang sudah banyak yang berguguran. Pada awal berdiri koperasi pada tahun 2008 jumlah anggota sebanyak 22 anggota. Setiap tahun jumlah anggota terus bertambah walau tidak banyak. Pada akhir tahun 2020 jumlah anggota menjadi 102 0rang. Calon Anggota 300 orang Dengan total (modal sendiri berjumlah sekitar Rp. 80 Juta. Namun total aktiva sebesar 290 juta. 


\section{Struktur Anggota}

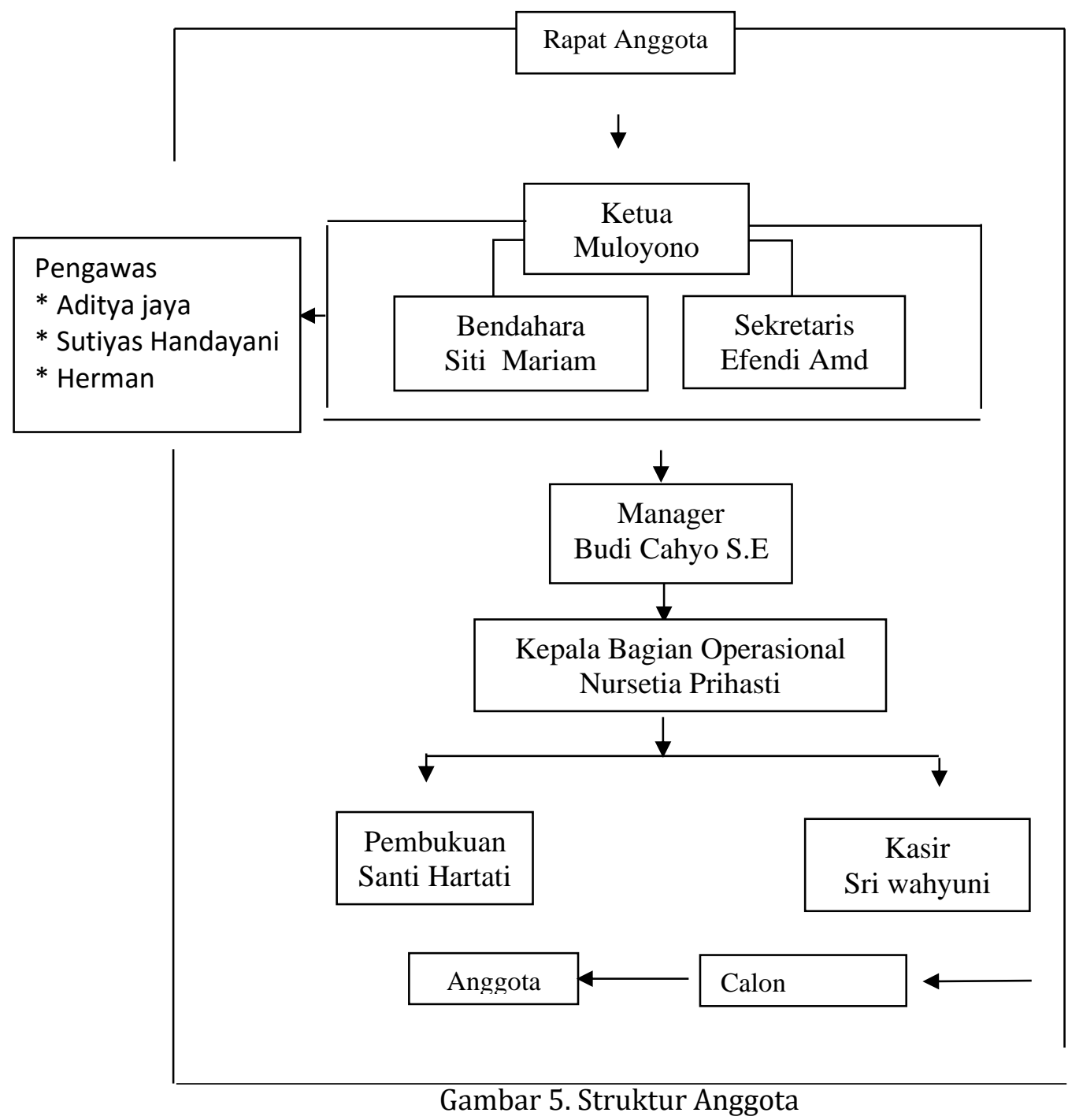

\section{c. Data Anggota Koperasi}

Tabel.1 Data Pribadi Anggota Koperasi

\begin{tabular}{|c|c|c|c|c|c|c|}
\hline No & $\begin{array}{l}\text { Nomor } \\
\text { Urut }\end{array}$ & Nama & Jenis Kelamin & Alamat & Pekerjaan & Ket \\
\hline 1 & AT-07001 & $\begin{array}{l}\text { Muliyono } \\
\text { S.Pd.I }\end{array}$ & Laki-Laki & $\begin{array}{l}\text { Komplek Mis Al- } \\
\text { Hidayah }\end{array}$ & Guru & \\
\hline 2 & AT-07003 & Aditya Jaya & Laki-Laki & Namo Lamdur & Kades & \\
\hline 4 & AT-07005 & Herman & Laki-Laki & Namo Lamdur & Wiraswasta & \\
\hline 5 & AT-07006 & Pariem & Perempuan & Namo Lamdur & $\begin{array}{l}\text { Ibu Rumah } \\
\text { Tangga }\end{array}$ & \\
\hline 6 & AT-07007 & Khairiah S,pd.i & Perempuan & $\begin{array}{l}\text { Komplek Mis Al- } \\
\text { Hidayah }\end{array}$ & Guru & \\
\hline 7 & AT-07008 & $\begin{array}{l}\text { Siti Mariam } \\
\text { S.pd }\end{array}$ & Perempuan & $\begin{array}{l}\text { Dusun } 1 \text { Namo } \\
\text { Landur }\end{array}$ & Guru & \\
\hline 8 & AT-07009 & Kartini & Perempuan & Namo Lamdur & Guru & \\
\hline 9 & AT-07010 & $\begin{array}{l}\text { Sutiyas } \\
\text { Handayani }\end{array}$ & Perempuan & Jati Kesuma & & \\
\hline 10 & AT-07011 & Muhammad & Laki-Laki & Namo Lamdur & Guru & \\
\hline
\end{tabular}




\begin{tabular}{|c|c|c|c|c|c|}
\hline & & Efendi & & & \\
\hline 11 & AT-07012 & Yenni Vidia & Perempuan & Dusun III & Guru \\
\hline 12 & AT-07013 & Rostina & Perempuan & Jati Kesuma & $\begin{array}{l}\text { Ibu Rumah } \\
\text { Tangga }\end{array}$ \\
\hline 13 & AT-07014 & Sunarti & Perempuan & $\begin{array}{l}\text { Jati Kesuma DSN } \\
1\end{array}$ & $\begin{array}{l}\text { Ibu Rumah } \\
\text { Tangga }\end{array}$ \\
\hline 14 & AT-07015 & $\begin{array}{l}\text { Yeni } \\
\text { Rahmadani }\end{array}$ & Perempuan & $\begin{array}{l}\text { Jati Kesuma DSN } \\
1\end{array}$ & $\begin{array}{l}\text { Ibu Rumah } \\
\text { Tangga }\end{array}$ \\
\hline 15 & AT-07017 & Heni Wati & Perempuan & Jati Kesuma & $\begin{array}{l}\text { Ibu Rumah } \\
\text { Tangga }\end{array}$ \\
\hline 16 & AT-07018 & Budi Cahyono & Laki-Laki & Namo Lamdur & $\begin{array}{l}\text { Manager } \\
\text { Kopsyah }\end{array}$ \\
\hline 17 & AT-07019 & Susi Aisyah & Perempuan & $\begin{array}{l}\text { Vila Mutiara } \\
\text { Johor }\end{array}$ & \\
\hline 18 & AT-07020 & M.Rusli & Laki-Laki & Namo Lamdur & wiraswasta \\
\hline 19 & AT-07021 & Lindawati & Perempuan & Dusun III & $\begin{array}{l}\text { Ibu Rumah } \\
\text { Tangga }\end{array}$ \\
\hline 20 & AT-07022 & $\begin{array}{l}\text { Irwansyah } \\
\text { Putra }\end{array}$ & Laki-Laki & Namo Lamdur & wiraswasta \\
\hline 21 & AT-07023 & Nurasiah & Perempuan & Dusun III & $\begin{array}{l}\text { Ibu Rumah } \\
\text { Tangga }\end{array}$ \\
\hline 22 & AT-07024 & $\begin{array}{l}\text { Nanda } \\
\text { Miranda }\end{array}$ & Perempuan & Namo Lamdur & Guru \\
\hline 24 & AT-07026 & Sri Siswati & Perempuan & $\begin{array}{l}\text { Dusun III } \\
\text { Gg.Sepakat }\end{array}$ & $\begin{array}{l}\text { Ibu Rumah } \\
\text { Tangga }\end{array}$ \\
\hline 25 & AT-07027 & $\begin{array}{l}\text { Fajariah } \\
\text { Supingi }\end{array}$ & Perempuan & Jati Kesuma & Guru \\
\hline 26 & AT-07028 & Tukini & Perempuan & Namo Lamdur & Guru \\
\hline 27 & AT-07029 & $\begin{array}{l}\text { Suranta kaca } \\
\text { ribu }\end{array}$ & Perempuan & Namo RAMBE & $\begin{array}{l}\text { Ibu Rumah } \\
\text { Tangga }\end{array}$ \\
\hline 29 & AT-07031 & Mila Sari & Perempuan & $\begin{array}{l}\text { Jl. Perintis } \\
\text { Kemerdekaan }\end{array}$ & \\
\hline 30 & AT-07032 & Susilawati & Perempuan & Deli tua & Guru \\
\hline 31 & AT-07033 & Rika Yuliana & Perempuan & Deli tua & Guru \\
\hline 32 & AT-07034 & $\begin{array}{l}\text { Halimatussak d } \\
\text { diah S.p }\end{array}$ & Perempuan & Dusun 1 & Guru \\
\hline 33 & AT-07035 & $\begin{array}{l}\text { Fauzia } \\
\text { Anggraeny S.p }\end{array}$ & Perempuan & $\begin{array}{l}\text { Lk. VI comp } \\
\text { pisu/23 }\end{array}$ & Guru \\
\hline 34 & AT-07036 & Rani S.pd & Perempuan & Dusun III & Guru \\
\hline 35 & AT-07037 & $\begin{array}{l}\text { Rahim } \\
\text { Purnomo S.pd }\end{array}$ & Laki-Laki & Jati Kesuma & Guru \\
\hline 36 & AT-07038 & Sugito S.pd & Laki-Laki & $\begin{array}{l}\text { Dusun lll gg } \\
\text { madrasyah }\end{array}$ & Guru \\
\hline 38 & AT-07040 & $\begin{array}{l}\text { Edeni Rama } \\
\text { S.Pd }\end{array}$ & Perempuan & $\begin{array}{l}\text { Dusun lll desa jati } \\
\text { kusuma }\end{array}$ & Guru \\
\hline 39 & AT-07041 & $\begin{array}{l}\text { Aliani } \\
\text { Syahfitri S.pd }\end{array}$ & Perempuan & $\begin{array}{l}\text { DUSUN Lv } \\
\text { g.masjid }\end{array}$ & Guru \\
\hline 40 & AT-07042 & $\begin{array}{l}\text { Gita Agustia } \\
\text { S.pd }\end{array}$ & Perempuan & Batu Rejo & Guru \\
\hline 41 & AT-07043 & Sarwono & Laki-Laki & Namo Lamdur & supir bus \\
\hline 42 & AT-07044 & $\begin{array}{l}\text { Diah Syahfitri } \\
\text { S.pd }\end{array}$ & Perempuan & Jati Kesuma & Guru \\
\hline
\end{tabular}




\begin{tabular}{|c|c|c|c|c|c|}
\hline 45 & AT-07046 & Erni S.ag & Perempuan & Dusun 1 & Guru \\
\hline 46 & AT-07047 & Bantu Bancin & Laki-Laki & Dusun 1 & \\
\hline 47 & AT-07048 & Ngadiman & Laki-Laki & Jati Kesuma & $\begin{array}{l}\text { Wira } \\
\text { Swasta }\end{array}$ \\
\hline 48 & AT-07049 & suhardani & Laki-Laki & Jati Kesuma & \\
\hline 50 & AT-07051 & Makmur & Laki-Laki & Namo Lamdur & $\begin{array}{l}\text { Wira } \\
\text { Swasta }\end{array}$ \\
\hline 52 & AT-07053 & $\begin{array}{l}\text { Mulyono } \\
\text { Syahputra }\end{array}$ & Laki-Laki & Dsn I & \\
\hline 53 & AT-07054 & Rumi Andriani & Perempuan & Namo Lamdur & $\begin{array}{l}\text { Ibu rumah } \\
\text { tangga }\end{array}$ \\
\hline 57 & AT-07058 & Lindanawati & Perempuan & Jati Kesuma & $\begin{array}{l}\text { Ibu rumah } \\
\text { tangga }\end{array}$ \\
\hline 58 & AT-07059 & $\begin{array}{l}\text { Hally } \\
\text { Rismadani }\end{array}$ & Perempuan & Jati Kesuma & $\begin{array}{l}\text { Ibu rumah } \\
\text { tangga }\end{array}$ \\
\hline 59 & AT-07060 & Sri & Perempuan & Jati Kesuma & PNS \\
\hline 61 & AT-07062 & Sri Farwanti & Perempuan & Jati Kesuma & \\
\hline 62 & AT-07063 & Juliana Arianti & Perempuan & Jati Kesuma & $\begin{array}{l}\text { Ibu rumah } \\
\text { tangga }\end{array}$ \\
\hline 63 & AT-07064 & Sugeng & Laki-Laki & Jati Kesuma & \\
\hline 64 & AT-07065 & Bambang & Laki-Laki & Psr 2 Sudirejo & \\
\hline 65 & AT-07066 & Santi Hartati & Perempuan & Jati Kesuma & Mahasiswa \\
\hline 66 & AT-07067 & Nurjannah & Perempuan & Namo Rambe & $\begin{array}{l}\text { Wira } \\
\text { Swasta }\end{array}$ \\
\hline 67 & AT-07068 & Semi Aswani & Perempuan & Jati Kesuma & $\begin{array}{l}\text { Ibu rumah } \\
\text { tangga }\end{array}$ \\
\hline 68 & AT-07069 & Sri Eka Wati & Perempuan & Jati Kesuma & $\begin{array}{l}\text { Ibu rumah } \\
\text { tangga }\end{array}$ \\
\hline 69 & AT-07070 & Eka Wijaya & Perempuan & Medan & \\
\hline 71 & AT-07072 & Raskita & Perempuan & Namo Lamdur & $\begin{array}{l}\text { Ibu Rumah } \\
\text { Tangga }\end{array}$ \\
\hline 73 & AT-07074 & Agus Tariya & Laki-Laki & Namo Lamdur & Mahasiswa \\
\hline 74 & AT-07075 & Sugiarni & Perempuan & Jati Kesuma & $\begin{array}{l}\text { Ibu rumah } \\
\text { tangga }\end{array}$ \\
\hline 75 & AT-07076 & Sumarningsih & Perempuan & Jati Kesuma & $\begin{array}{l}\text { Ibu rumah } \\
\text { tangga }\end{array}$ \\
\hline 76 & AT-07077 & Nurlela & Perempuan & Jati Kesuma & $\begin{array}{l}\text { Ibu rumah } \\
\text { tangga }\end{array}$ \\
\hline 77 & AT-07079 & Arsita & Perempuan & Dusun 1 & Guru \\
\hline 78 & AT-07080 & Nurjannah & Perempuan & Deli Tua & Guru \\
\hline 79 & AT-07081 & Siti Fatima & Perempuan & Pasar II & Guru \\
\hline 80 & AT-07082 & Sri Handayati & Perempuan & Jati Kesuma & $\begin{array}{l}\text { Ibu rumah } \\
\text { tangga }\end{array}$ \\
\hline 81 & AT-07083 & Meliana & Perempuan & Jati Kesuma & $\begin{array}{l}\text { Ibu rumah } \\
\text { tangga }\end{array}$ \\
\hline 82 & AT-07084 & Muliadi & Perempuan & Jati Kesuma & $\begin{array}{l}\text { Wira } \\
\text { Swasta }\end{array}$ \\
\hline 83 & AT-07085 & Misniati & Perempuan & Jati Kesuma & $\begin{array}{l}\text { Ibu rumah } \\
\text { tangga }\end{array}$ \\
\hline 84 & AT-07086 & Marsiyem & Perempuan & Jati Kesuma & $\begin{array}{l}\text { Ibu rumah } \\
\text { tangga }\end{array}$ \\
\hline 85 & AT-07087 & Suyati & Perempuan & Jati Kesuma & $\begin{array}{l}\text { Ibu rumah } \\
\text { tangga }\end{array}$ \\
\hline 86 & AT-07088 & Estanaria & Perempuan & Jati Kesuma & Ibu rumah \\
\hline
\end{tabular}




\begin{tabular}{|c|c|c|c|c|c|}
\hline 87 & AT-07089 & Ponirah & Perempuan & Jati Kesuma & $\begin{array}{l}\text { tangga } \\
\text { Ibu rumah } \\
\text { tangga }\end{array}$ \\
\hline 89 & AT-07091 & Dewi Erika & Perempuan & Jati Kesuma & $\begin{array}{l}\text { Ibu rumah } \\
\text { tangga }\end{array}$ \\
\hline 90 & AT-07092 & Dini Triana & Perempuan & Jati Kesuma & $\begin{array}{l}\text { Ibu rumah } \\
\text { tangga }\end{array}$ \\
\hline 91 & AT-07093 & Sri Wahyuni & Perempuan & Jati Kesuma & $\begin{array}{l}\text { Ibu rumah } \\
\text { tangga }\end{array}$ \\
\hline 92 & AT-07094 & Herwinda & Perempuan & Namo Rambe & $\begin{array}{l}\text { Ibu rumah } \\
\text { tangga }\end{array}$ \\
\hline 95 & AT-07097 & Sofiani Amzar & Perempuan & Jati Kesuma & $\begin{array}{l}\text { Ibu rumah } \\
\text { tangga }\end{array}$ \\
\hline 96 & AT-07098 & Astuti & Perempuan & $\begin{array}{l}\text { Jati Kesuma Dsn. } \\
\text { III }\end{array}$ & $\begin{array}{l}\text { Wira } \\
\text { Swasta }\end{array}$ \\
\hline
\end{tabular}

\section{PEMBAHASAN}

\section{Asas dan Landasan BMT}

BMT berasaskan Pancasila dan UUD 45 serta berlandaskan prinsip syariah islam, keimanan, keterpaduan (kaffah), kekeluargaan / koperasi, kebersamaan, kemandirian dan profesionalisme. Dengan demikian keberadaan BMT menjadi organisasi yang sah dan legal. Sebagi lembaga keuangan syariah, BMT harus berpegang teguh pada prinsip-prinsip syariah. Keimanan menjadi landasan atas keyakinan untuk mau tumbuh dan berkembang. Keterpaduan mengisyaratkan adanya harapan untuk mencapai sukses di dunia dan di akhirat juga keterpaduan antara sisi maal dan tamwil (sosial dan bisnis). Kekeluargaan dan kebersamaan berarti upaya untuk mencapai kesuksesan tersebut diraih secara bersama. Kemandirian berarti BMT tidak dapat hidup hanya dengan bergantung pada uluran tangan pemerintah, tetapi harus berkembang dari meningkatnya partisipasi anggota dan masyarakat, untuk itulah pola pengelolaannya harus professional. Prinsip Dasar BMT adalah:

a. Ahsan (mutu hasil kerja yang terbaik)Thayyiban (terindah), Ahsanu'amala (memuaskan semua pihak) dan sesuai dengan nilai-nilai salaam (keselamatan, kedamaian dan kesejahteraan).

b. Barakah, artinya berdaya guna, berhasil guna, adanya penguatan jaringan, transparan (keterbukaan), dan bertanggung jawab sepenuhnya kepada masyarakat.

c. Spiritual Communication (penguatan nilai ruhiyah).

d. Demokratis, partisipatif dan inklusif.

e. Keadilan sosial dan kesetaraan gender, non-diskriminatif.

f. Ramah Lingkungan,

g. Peka dan bijak terhadap pengetahuan dan budaya lokal, serta keanekaragaman budaya.

h. Keberlanjutan, memberdayakan masyarakat dengan meningkatkan kemampuan diri dan lembaga masyarakat lokal.

2. Fungsi BMT

a. Mengidentifikasi, memobilisasi, mengorganisasi, mendorong dan mengembangkan potensi ekonomi anggota, kelompok anggota muamalat (Pokusma) dan daerah kerjanya.

b. Meningkatkan kualitas SDM anggota dan pokusma menjadi professional dan islami sehingga semakin utuh dan tangguh dalam menghadapi persaingan global.

c. Menggalang dan memobilisasi potensi masyarakat dalam rangka meningkatkan kesejahteraan anggota.

d. Menjadi perantara keuangan antara agnia (yang berhutang) sebagai shahibul maal dengan dhuafa sebagai mudharib, terutama untuk dana sosial seperti zakat, infaq, sedekah wakaf hibah dll. 
e. Menjadi perantara keuangan antara pemilik dana baik sebagai pemodal maupun penyimpan dengan pengguna dana untuk pengembangan usaha produktif.

3. Tujuan BMT

Didirikannya BMT dengan tujuan meningkatkan kualitas usaha ekonomi untuk kesejahteraan anggota pada khususnya dan masyarakat pada umumnya. Pengertian tersebut dapat dipahami bahwa BMT berorientasi pada upaya peningkatan kesejahteraan anggota dan masyarakat. Anggota harus diberdayakan supaya dapat mandiri. Dengan sendirinya, tidak dapat dibenarkan jika para anggota dan masyarakat menjadi sangat tergantung kepada BMT. Dengan menjadi anggota BMT, masyarakat dapat meningkatkan taraf hidup melalui peningkatan usahanya.

Pemberian modal pinjaman sedapat mungkin dapat memandirikan ekonomi para peminjam. Oleh sebab itu, perlu dilakukan pendampingan. Dalam pelemparan pembiayaan, BMT harus dapat menciptakan suasana keterbukaan, sehingga dapat mendeteksi berbagai kemungkinan yang timbul pada pembiayaan. Untuk mempermudah pendampingan, pendekatan pola kelompok menjadi sangat penting. Anggota dikelompokkan berdasarkan usaha sejenis atau kedekatan tempat tinggal, sehingga BMT dapat dengan mudah melakukan pendampingan.

4. Produk dan BMT

\section{a. Pembiayaan}

1) Pembiyaan modal kerja

Penyediaan kebutuhan modal kerja dapat diterapkan dalam berbagai kondisi dan kebutuhan, karena memang produk BMT sangat banyak sehingga memungkinkan dapat memenuhi kebutuhan modal tersebut.

2) Pembiayaan berdasarkan prinsip jual beli Merupakan penyediaan barang modal maupun investasi untuk pemenuhan kebutuhan modal kerja maupun investasi. Atas transaksi ini BMT mendapat sejumlah keuntungan.

3) Pembiayaan dengan prinsip jasa Pembiayaan ini disebut jasa karena pada prinsipnya dasar akadnya adalah ta'auni atau tabarru'I yakni akad yang tujuannya tolong-menolong dalam hal kebajikan.

\section{b. Produk Tabungan}

1) Tabungan Pendidikan: merupakan tabungan yang disetorkan kapan saja namun pengambilannya sesuai perjanjian. Misalnya, 6 bulan, 1 tahun, 2 tahun dan 4 tahun.

2) Tabungan Biasa: tabungan yang kapan saja bias di ambil dan terdapat sistem bagi hasil.

3) Tabungan Idul Fitri : tabungan yang diambil satu tahun sekali dan diambilnya sebelum idul fitri.

4) Tabungan Aqiqah : tabungan yang diambilnya pada saat akan melakukan aqiqah.

5) Tabungan Haji : tabungan yang disetorkan untuk membiayai ibadah haji yang akan dilakukan oleh penyetor.

6) Tabungan Qurban : tabungan yang disetorkan untuk membiayai ibadah qurban.

\section{Mekanisme Operasional BMT}

Dikelola oleh Manajer, Teller, Marketting dan Pengurus. Dan BMT dibawah bimbingan kementrian kopersai dan UKM ( Usaha Kecil Menengah ). Selain itu BMT juga mempunyai visi dan misi agar mekanisme operasionalnya berjalan dengan baik. Diantaranya adalah:

Visi : Harus mengarah pada upaya untuk mewujudkan BMT menjadi lembaga yang mampu meningkatkan kualitas ibadah, memakmurkan kehidupan anggota pada khususnya dan masyarakat pada umumnya.

Misi : Membangun dan mengembangkan tatanan perekonomian dan struktur masyarakat madani yang adil bermakmuran, berkemajuan, serta makmur, maju, berkeadilan, berlandaskan Syariah dan ridho Allah SWT. 


\section{Modal Pendirian BMT}

BMT dapat didirikan dengan modal Rp 20.000.000 atau lebih. Namun demikian, terdapat kesulitan dalam mengumpulkan modal awal, dapat dimulai dengan modal $\mathrm{Rp} 10.000 .000$ bahkan Rp 5.000.000. modal awal ini dapat berasal dari satu atau beberapa tokoh masyarakat setempat, yayasan, kas masjid atau BAZIS setempat. Namun sejak awal anggota pendiri BMT harus terdiri antara 20 sampai 44 orang. Jumlah batasan 20 sampai 44 anggota pendiri, ini diperlukan agar BMT menjadi milik masyarakat setempat.

7. Badan Pendirian BMT

BMT dapat didirikan dalam bentuk kelompok Swadaya Masyarakat atau koperasi.

a. KSM adalah Kelompok Swadaya Masyarakat dengan mendapat Surat Keterangan Operasional dan PINBUK (Pusat Inkubasi Bisnis Usaha Kecil)

b. Koperasi serba usaha atau koperasi syariah

c. Koperasi simpan pinjam syariah ( KSP-S )

8. Tahap Pendirian BMT

Adapun tahap-tahap yang perlu dilakukan dalam pendirian BMT adalah sebagai berikut:

a. Pemrakarsa membentuk panitia penyiapan pendirian BMT (P3B) di lokasi tertentu seperti masjid, pesantren, desa miskin, kelurahan dan lainnya.

b. P3B mencari modal awal atau modal perangsang sebesar Rp 5.000 .000 sampai Rp 10.000.000 atau lebih besar mencapai Rp 20.000.000 untuk segera memulai langkah operasional. Modal awal ini dapat berasal dari perorangan, lembaga, yayasan, BAZIS, Pemda atau sumber-sumber lainnya.

c. Atau langsung mencari mencari permodalan pendiri dari sekitar 20 sampai 44 orang dikawasan itu untuk mendapatkan dana urunan hingga mencapai jumlah $\mathrm{Rp}$ 20.000.000 atau minimal Rp 5.000.000

d. Jika calon pemodal telah ada maka dipilih pengurus yang ramping ( 3-5 orang) yang akan mewakili pendiri dalam mengerahkan kebvijakan BMT.

e. Memilih 3 calon pengelola (minimal berpendidikan D3 dan lebih baik S1) dengan menghubungi Pusdiklat PINBUK Provinsi atau Kab/Kota.

f. Melaksanakan persiapan-persiapan sarana perkantoran dan formulir yang diperlukan.

g. Menjalankan bisnis operasi BMT secara profesional dan sehat.

\section{KESIMPULAN}

Perkembangannya, BMT memang tidak memiliki badan hukum resmi. BMT berkembang sebagai Kelompok Swadaya Masyarakat (KSM) atau Kelompok Simpan Pinjam (KSP). Namun, untuk mengantisipasi perkembangan ke depan, status hukum menjadi kebutuhan yang mendesak. Dalam peraturan perundang-undangan di Indonesia, yang memungkinkan penerapan sistem operasi bagi hasil adalah perbankan dan koperasi. Saat ini, oleh lembaga-lembaga pembina BMT yang ada, BMT diarahkan untuk berbadan hukum koperasi mengingat BMT berkembang dari kelompok swadaya masyarakat. Selain itu, dengan berbentuk koperasi, BMT dapat berkembang ke berbagai sektor usaha seperti keuangan dan sektor riil. Bentuk ini juga diharapkan dapat memenuhi tujuan memberdayakan masyarakat luas, sehingga kepemilikan kolektif BMT sebagaimana konsep koperasi akan lebih mengenai sasaran.

Didirikannya BMT dengan tujuan meningkatkan kualitas usaha ekonomi untuk kesejahteraan anggota pada khususnya dan masyarakat pada umumnya. Pengertian tersebut dapat dipahami bahwa BMT berorientasi pada upaya peningkatan kesejahteraan anggota dan masyarakat. Anggota harus diberdayakan supaya dapat mandiri. Dengan sendirinya, tidak dapat dibenarkan jika para anggota dan masyarakat menjadi sangat tergantung kepada BMT. Dengan menjadi anggota BMT, masyarakat dapat meningkatkan taraf hidup melalui peningkatan usahanya. 
Pemberian modal pinjaman sedapat mungkin dapat memandirikan ekonomi para peminjam. Oleh sebab itu, perlu dilakukan pendampingan. Dalam pelemparan pembiayaan, BMT harus dapat menciptakan suasana keterbukaan, sehingga dapat mendeteksi berbagai kemungkinan yang timbul pada pembiayaan. Untuk mempermudah pendampingan, pendekatan pola kelompok menjadi sangat penting. Anggota dikelompokkan berdasarkan usaha sejenis atau kedekatan tempat tinggal, sehingga BMT dapat dengan mudah melakukan pendampingan.

\section{DAFTAR PUSTAKA}

[1] Keputusan Mentri Koperasi dan Pembinaan Pengusaha Kecil Republik Indonesia nomor : 194/KEP/M/IX/1998 tentang Petujuk Pelaksanaan Penilaian Kesehatan Koperasi Simpan Pinjam dan Unit Simpan Pinjam. 1999. Jakarta: Direktorat Jendral Fasilitas Pembiayaan dan Simpan Pinjam.

[2] I. Mafruhah, "Membumikan Konsep Syariah Dalam Ekonomi Berbasis Kerakyatan (Baitul Maal Wat Tamwil Sebagai Sebuah Solusi)," Jurnal Ekonomi Pembangunan, Vol. 3, No 2, pp. 195-2015, 2012

[3] J. Muhammad, Profil BMT Indonesia (BMT CENTER), Jakarta : BMT Center, 2013.

[4] A. Sjartuni, Tuntunan Praktis Dasar - Dasar Pemprograman Visual Basic, Jakarta : PT. Elek Media Komputindo, 2012.

[5] D. U. Daihani, Komputerisasi Pengambilan Keputusan, Jakarta: PT Elex Media Komputindo, 2011.

[6] A. Kadir, Konsep dan tuntunan Praktis Basis Data, Bandung: PT.Sukses Maju, 2013.

[7] Arif, M. Nur Rianto. Lembaga Keuangan Syariah. Bandung: CV. PUSTAKA SETIA. 2012.

[8] PINBUK, Pedoman Cara Pembentukan BMT, (Jakarta, PT. Bina Usaha Indonesia, $\mathrm{tt}$ )

[9] M. Ridwan, Manajemen Baitul Maal Wa Tamwil ( BMT ), Yogyakarta: UII Press Yogyakarta, 2014.

[10] M. D. Raharjo, Perspektif Dkelarasi Makkah, Menuju Ekonomi Islam, Bandung : mizan, 2011.

[11] H. Sudarsono, Bank dan Lembaga Keuangan Syariah Deskripsi dan Ilustrasi, Cet. 2, Yogyakarta: Ekonisia, 2012. 